\title{
Consumer Preferences and Segmentation Analysis of Bogor Culinary Tourism
}

\author{
Ira Agustina* \\ Magister Manajement and \\ Business, School of Business \\ Bogor Agricultural University
}

\author{
Ujang Sumarwan \\ Magister Manajement and \\ Business, School of Business \\ Bogor Agricultural University
}

\author{
Kirbrandoko \\ Magister Manajement and \\ Business, School of Business \\ Bogor Agricultural University
}

*Corresponding author: iragustina26@gmail.com

\begin{abstract}
This study was conducted to analyze the segmentation \& profiling Bogor tourists, analyze consumer preferences towards typical culinary Bogor and the factors that influence them, and formulate appropriate strategies for the development of the typical culinary Bogor. This research used descriptive method survey. Segmentation and profiling analysis performed on the tourist city of Bogor were done with the help of a cluster analysis. For the second objective of this study, this used conjoint analysis to formulate a preference rating of Bogor to the typical culinary travel Bogor. Both of these analyzes were processed using an analysis tool SPSS 16.0. The results showed that there were three groups/ clusters on the tourist city of Bogor. Cluster i.e. one single adult was as much as 23 percent, and cluster of two adult family was as much as 71 percent, and the last cluster of young adults was as much as 6 percent. Traveler preferences resulting from this study were typical culinary areas of Bogor which had complete tourist facilities, ease of sitting, and friendly service. The strategy that can be formulated for the development of the typical culinary Bogor is a breakthrough in terms of marketing, promotion of standardization policy by the government to businesses typical culinary Bogor, as well as the central building typical culinary Bogor.
\end{abstract}

Keywords: preferences, segmentation, conjoint, cluster, culinary Bogor

\begin{abstract}
Abstrak. Penelitian ini dilakukan untuk menganalisis segmentasi \& profiling wisatawan kota Bogor, menganalisis preferensi konsumen terhadap wisata kuliner khas Bogor dan faktor-faktor yang mempengaruhinya,serta merumuskan strategi yang tepat untuk pengembangan wisata kuliner khas Bogor. Penelitian ini menggunakan metode deskriptif dengan pendekatan survei. Analisis segmentasi dan profiling yang dilakukan pada wisatawan Kota Bogor dilakukan dengan bantuan analisis kluster. Untuk tujuan ke dua penelitian ini digunakan analisis konjoin untuk merumuskan preferensi dari wisatawan Kota Bogor terhadap wisata kuliner khas Bogor. Kedua analisis ini diolah menggunakan alat analisis SPSS 16.0. Hasil penelitian ini menunjukkan terdapat tiga kelompok/kluster pada wisatawan Kota Bogor. Kluster satu yaitu dewasa single sebanyak 23 persen, kluster 2 dewasa berkeluarga sebanyak 71 persen dan kluster terakhir dewasa muda sebanyak 6 persen dengan karakteristik yang berbeda-beda. Preferensi wisatawan yang dihasilkan dari penelitian ini adalah tempat wisata kuliner khas Bogor yang memiliki fasilitas wisata yang lengkap, kemudahan dalam pencarian lokasinya, serta pelayanan yang ramah dari tempat wisata kuliner tersebut. Strategi yang dapat dirumuskan untuk pengembangan wisata kuliner khas Bogor adalah melakukan terobosan dalam hal pemasaran, adanya atau penggalakan standarisasi kebijakan oleh pemerintah terhadap pelaku usaha kuliner khas Bogor, serta membangun sentral wisata kuliner khas Bogor.
\end{abstract}

Kata Kunci : preferensi, segmentasi,konjoin, kluster, wisata kuliner Bogor 


\section{Introduction}

Tourism in Indonesia is an important economic sector in Indonesia. In 2009, tourism got the third rank in terms of foreign exchange earnings after oil and gas commodities and palm oil. Based on the data from 2014, the number of foreign tourists coming to Indonesia amounted to 9.4 million, an increase of 7.05 percent over the previous year. Natural and cultural resources are important components of tourism in Indonesia. Moreover, tourist attractions are supported by a rich cultural heritage which will be a reflection of history and ethnic diversity of Indonesia's dynamic with a variety of regional specialties respectively. This is consistent with the shift in current tourism trends, that is, the change of the massive tourism into individual tourism/ small group of tourism. Quantity is no longer the main thing pursued, but the quality of the travel itself (Suherman, 2015).

Individual/ small group of tourism that tends to pursue a quality makes this trend of tourism type is tourism with special interests. Special interest tourism is tourism mean focused on the idea to get a unique experience which can not be found elsewhere. Seven sectors of special interest tourism developed in Indonesia are a historical and cultural tourism, nature tourism and ecotourism, culinary and shopping, meeting tourism, incentive, convention, exhibition (MICE), sports and leisure tourism, cruise tourism and spa tourism.

West Java province is one of the objectives of Indonesian society to enjoy the wealth of special interest tour in Indonesia. Bogor city which is part of West Java province can provide a wealth of various tours. Geographic strategic position certainly makes the tourism potential of the Bogor city. Ease of access to the achievement of the Jakarta and Bandung capital, West Java Capital, making the Bogor city has the potential of being a counter magnet or short escape for Jakarta and Bandung tourists. It is also evident from the development of domestic tourists that continues to increase each year to the city that has a nickname "Rain City" (Department of Culture and Tourism of the city of Bogor, 2014).

Nowadays we can see that the modern culinary tour has dominated the existence of the typical culinary tour of Bogor. Despite an increase in tourists to the Bogor city, meaning also an increase of demand for tourism products, Bogor typical culinary tour requires government assistance in the effort to overcome the dominance of modern culinary tour destinations.

Judged from the GDP at Current Market Prices Sectors Trade, Hotel and Restaurant is the sector with the highest sectoral contribution in Bogor, i.e. 36.65 percent. This overview of sectoral contribution is very suitable to the characteristics of Bogor city as urban areas. Therefore, it needs better attention from the investors to the culinary sector, particularly typical culinary from Bogor to find out how the behavior of consumers in order to bring consumers in large quantities.

Consumer behavior can be seen from how cunsumers make a decision. In the decision-making process, there are four stages experienced by prospective buyers, i.e. aware of the need, search for information, evaluate alternatives and ultimately decision-making. Phase of evaluate alternatives plays an important role in decision-making, because if all the needs of the consumers can be met by a single product, the tendency of consumers to buy products will also increase. 
Judged from research Kivela (1997), there are four factors driving consumers to eat at the restaurant: only to eat, to have a social meeting, to meet business associates and to celebrate an event. These four driving factors also change consumer behavior in choosing Bogor typical culinary tour.

Some research at domestic and overseas that has been carried out on a culinary tour of a region has the perception and different results. Amuquandoh (2013) and Vanhonacker (2010) have the same research which revolves around the traditional food in a country, but has different research objects. Research in Ghana which focused on traditional foods consumed by tourists became the research object, while Vanhonackerdan friends see traditional European food consumers as research object. From the traditional food preferences obtained from the research results in Ghana, it is known that packaging, service quality and hygiene conditions of places to eat themselves are things that should be improved and maintained. While the results of consumer research traditional European food, it is known that consumer profiles of midlife up are aware of health, love their country and cooking.

Research by Swantari (2013) and Guler (2016) aimed to determine the potential of a regional culinary and consumer preference towards local food in Turkey. Culinary tourism potential was analyzed using SWOT analysis. One of the results was the potential power of culinary tourism in the form of a strategic location, while the preference of local food Turkish was analyzed with conjoint analysis with data obtained from 154 questionnaires given by the respondents at random or convenience sampling. The conclusion of this study also revealed that consumers were willing to pay expensive prices for food products, especially the main meals if the product was deemed worthy or good.

Research by Adiyoga (2012), Syarir (2015), and Mulyadi (2014) conducted on three different commodities has the same purpose in the form of preferences of consumers. However, an analysis tool used is different. In the analysis of duck meat researchers used a ChochranQ Test and analysis of multi Fish Bein attribute with the result attributes which become the consideration of the merchants, such as the price of the carcass, carcass weight, uniform of carcass, hygiene of carcasses, flesh color, aroma of carcass, and the resilience of carcasses, whereas in rice research labeled and instant noodles, researchers used conjoint analysis to analyze the attributes of each commodity. Both studies have resulted in the attributes used which basically are similar, i.e. prices and physical commodities themselves.

In this research, analyzis conducted was different from previous studies. The object of this research was typical culinary tour of Bogor city and its subject was tourist of Bogor city. Based on the description of the problems mentioned above, the purposes of this study were : (1) analyze the segmentation and profiling Bogor tourist; (2) analyze the consumer preference on Bogor typical culinary tour and the factors that influence it; and (3) formulate appropriate strategies for the development of Bogor typical culinary tour. 


\section{Method}

This research used descriptive method with survey approach by distributing questionnaires to people who are willing to become respondents in this study. Sumarwan (2011), stated that the descriptive study aimed to describe something usually a characteristic or function of the market. The respondents were consumers aged 15 years and over, which were already considered to be responsible for the purchasing decision of a product or service, that is, the Bogor typical culinary. In this study, the data used were 100 tourist respondents. The data were obtained by purposive sampling method (domicile outside the city of Bogor). They visited the city of Bogor in the last 6 months with an age limit of 15 years and above. Respondents were asked to fill out questionnaires remedy by answering a few questions about the profile of respondents, purchase behavior and consumption of Bogor typical culinary and the preferences of respondents to attribute a distinctive culinary Bogor and the factors influencing it.

Interviews conducted in person with a guide questionnaire were to obtain information about consumer preferences and segmentation of Bogor typical culinary tour filled directly by the respondents. Observations were conducted to obtain data and information for analyzing consumer preferences and segmentation of Bogor typical culinary tour. Data and other information were obtained from questionnaires given to respondents.

This research was located in Bogor city. Locations were selected purposively based on certain considerations in accordance with the purpose of research. This was taken based on the consideration by the researchers, namely a location that provided one or more of Bogor typical culinary tours in which the location was in the main streets of Bogor.

The analysis was used to mitigate or reduce the data in research into specific groups. The groups will show the differences and similarities based on the data obtained. The data from the survey were analyzed in cluster, that is, to classify respondents by similarity of features and number of existing attributes such as demographics, psychographics, satisfaction and others. Cluster analysis grouped the respondents into two or more groups. Each group was composed of respondents with attitude that relatively similar toward certain attributes.

The data obtained were analyzed in cluster with SPSS Program Assistance. In general, the following steps were performed:

1. Determine the existing groups first, such as the $X$ group

2. Specify the $X$ center randomly and each object was allocated to the group that was closest to the center.

3. Group center was then determined as the average of its members and the re-allocation process of objects was performed.

4. An object could be moved to another group if the object was closer to the center of another group.

5. This process was done iteratively until there was no further change in the grouping.

\section{Conjoint analysis}

Description of variables observed and measured in this study was set out to avoid mistakes in meaning and understanding the study. In this study, a 
favorite of Bogor city tourist to Bogor typical culinary tour was a dependent variable in which this variable would later be influenced by independent variables consisting of dependent attributes themselves and the indicators with a scale interval measurement of 1- 5. The questions given to the respondents are presented in the form of eight combinations of attributes which were done to 30 respondents out of 140 main respondents of Bogor city tourists in accordance with the purpose of this study.

Based on the results of the initial survey, there were three important attributes found with each level influencing tourist decisions in selecting Bogor typical culinary tour. These attributes consisted of product attributes, location and service presented completely in Table 1.

Table 1. Attributes on Bogor typical culinary tour

\begin{tabular}{|c|c|}
\hline Dimension & Attributes \\
\hline \multirow{4}{*}{ Product } & Tour facilities \\
\hline & Popularity of tour areas \\
\hline & Tour originality \\
\hline & Cost for tour \\
\hline \multirow[t]{2}{*}{ Location } & Location distance/time of tour \\
\hline & East of tour location search \\
\hline \multirow[t]{2}{*}{ Services } & Comfortability at tour areas \\
\hline & Friendly services \\
\hline
\end{tabular}

\section{Result And Discussion \\ Tourist Profile}

Profile data is important to know because different consumers would inevitably consume different products, in which in this study tourists of Bogor city are as consumers and Bogor City tour is the product (Sumarwan 2011). Characteristics measured in this study, among others, were a tour destination to the Bogor city, marital status, occupation, educational level, and expenditure spent on tourism to the Bogor city.

Table 2. Characteristics of tourists based on Tour Destination to Bogor city

\begin{tabular}{lc}
\hline \multicolumn{1}{c}{ Tour Destination } & Composition $(\%)$ \\
\hline Bisnis Tour & 13 \\
Culinary Tour & 55 \\
Shopping Tour & 7 \\
Natural Tour & 18 \\
Etcetera & 7 \\
\hline
\end{tabular}

Based on the characteristics of tourist destinations, those coming to Bogor city were to have culinary tours, which had the highest position - 55 percent, while business tour and natural tour were 13 percent and 18 percent, and shopping tour was 7 percent. 7 percent and more tourists visited Bogor city, in which two of them visited their family or just to have reminisce. In practice, most of the tourist destinations can be interconnected as a destination of business tour but can also be associated with culinary or nature tour for the number of companies conducting 
meetings and outing in Bogor city, but most tourists who deliberately came to Bogor city were to enjoy culinary tour provided by this Rain City.

Based on the characteristics of the respondents' work type, it could be found out that the biggest composition was employees working in private sectors -51 percent of all respondents. This type of work is one aspect that can affect a person's social status, in which this social status indirectly describes the differences in lifestyle, income, and the values espoused (Sumarwan, 1997). Characteristics of this work type are needed to describe the choice of visitors to this type of activity as well as the facilities and services required by tour, while other tourists came various types, namely the government employees by 24 percent, students by 17 percent of the respondents, entrepreneurs and other circles by 4 percent each.

Based on the characteristics of the education level, the data obtained showed that tourists were dominated by the undergraduate level as much as 46 percent in which this was sustainable with the number of tourists of Bogor city - mostly among workers. In addition, the level of college education had a composition of 28 percent, 18 percent of postgraduate and high school as much 8 percent. Distribution of respondents by education level can be sustainable with the characteristics of the work type of tourists. The average education of Bogor tourists working was graduate program above. This is consistent with the understanding that consumers with a better level of education are very responsive to information compared to those with low education (Sumarwan, 2004).

Table 3. Characteristics of tourists by type of employment and education level

\begin{tabular}{lclc}
\hline \multicolumn{1}{c}{ Job Type } & Composition (\%) & Education Level & Composition (\%) \\
\hline Students & 17 & High School & 8 \\
Private Employees & 51 & Academy & 28 \\
Government & 24 & Graduate & 46 \\
Employees & 4 & Post Graduate & 18 \\
Entrepreneur & 4 & & \\
Etcetera & & & \\
\hline
\end{tabular}

Expenditure was represented by costs incurred for traveling to Bogor city because travel expenditure per month was assumed to be the cost that consumers use for travelling, not only to the city of Bogor in one month. In addition, this will assist to determine the marketing strategy and service management that is most appropriate to the visitor. Of the 100 respondents, there was a group that had spent Rp 300.000 - Rp 500.000 which was equal to 41 percent, Rp 100.000 - Rp 300.000 by 30 percent and spending > Rp 500.000 by 29 percent. It can be seen that as many as 41 people spend Rp 300.000 - Rp 500.000 every time they travel to Bogor City.

Based on the marital status, 65 percent of respondents was non married group and 35 percent was married group. It can be stated that Bogor has been enjoyed by people who are still single, which will certainly affect the decision making process to conduct tours to Bogor city where usually for the age group above 15 years old and not married tends to make decisions because of social needs to do activities with peers 


\section{Segmentation of Bogor City Tourist Demography}

Segmentation towards Bogor city tourist was intended to help the tourism entrepreneurs in Bogor city to determine priorities for designing a marketing strategy of their business tourism. In this research, division of Bogor City tourism segment performed a k-means cluster analysis, which firstly began to determine the number of groups that will divide the tourist of Bogor city.

Based on the data and information obtained, Bogor City tourism can be divided into three clusters/ segments demographically with different variable consisting of occupation, marital status, intensity of a visit to Bogor city, tourism friend to Bogor city, the number of the group if in group, the duration of the visitation, expenditure for one tour visit to Bogor city, decision making, and purchasing of souvenirs after travelling (Table 4).

Table 4. Cluster of Bogor City tourists by visitor profile

\begin{tabular}{|c|c|c|c|}
\hline \multirow{2}{*}{ Variable } & \multicolumn{3}{|c|}{ Cluster/Group (Segment) } \\
\hline & $\mathrm{I}$ & II & III \\
\hline Tour Destination & Culinary Tour & Culinary Tour & Culinary Tour \\
\hline Occupation & Private Employees & $\begin{array}{l}\text { Private } \\
\text { Employees }\end{array}$ & Student \\
\hline Marital Status & Unmarried & Married & Unmarried \\
\hline Intensity of Visitation & $1-3$ times & 1 - 3 times & $>6$ times \\
\hline Tour Friends & Alone/friends & Family & Friends \\
\hline Total Group & $>10$ persons & $3-5$ persons & $3-5$ persons \\
\hline Duration of Visitation & $\begin{array}{l} \pm 6 \text { hours and didn't } \\
\text { stay }\end{array}$ & $\begin{array}{l}>6 \text { hours and } \\
\text { didn't stay }\end{array}$ & $\begin{array}{l}\text { stay more than one } \\
\text { night }\end{array}$ \\
\hline Spending on Tourism & $<250.000$ & $\begin{array}{l}\text { Rp } 250.000-R p \\
500.000\end{array}$ & $\begin{array}{l}\mathrm{Rp} 500.000-\mathrm{Rp} \\
1.000 .000\end{array}$ \\
\hline Decision Making & Depend on situation & Planned & Suddenly \\
\hline Purchasing Souvenir & Not buying & Yes & Yes \\
\hline
\end{tabular}

\section{Segmen I (Single Adults Segment)}

According to table 4, 23 percent of Bogor city tourists belongs to the segment of I/ single adult segment, that is, visitors whose job is usually private employee, unmarried status, with the intensity of visits 1-3 times a month. This segment often travelled alone and if they travelled in group, the group were usually big group (>10). The usually did not stay and did the travelling only \pm 6 hours so that they did not make purchases of souvenirs, and spent an average of Rp 250.000 (personal expenses). In addition, external factors influenced this segment in making decision to tourism to Bogor city. Therefore, the authors named this segment as a single adult segment.

The use of this name was based on the characteristics of the segment dominated by tourists from private employees who were not married, in which they tended to be busy on weekdays and do social activities, such as hang out or other hedonic activities with friends at the weekend. Based on the tourist profile of this first group, the first segment of the Bogor city tourists resulting from this study was single adult segment, namely:

a. adult visitors who have already worked (usually private employees) and single;

b. generally not in a group or do tourism with a partner (lover) or friends only; 
c. only have one tourism destination, for example, culinary tourism, which does not need to spend a lot of time;

d. do not need to spend a huge cost because they travel by themselves.

Most of this segment (43\%) had the same goal in the tour, that is, a culinary tour. Culinary tour usually visited by this segment was culinary time tourism which was the trending topic among their friends or social media, such as coffee shop. Moreover the location was also considered important for this segment because the viewing habits of young people today are always updated about events or holiday that they had even though they just ate at a restaurant.

\section{Segment II (Adults Family Segment)}

As much as 71 percent of tourists in Bogor city belongs to this second segment. Second segment was dominated by tourists working in the private sector and married or getting married. This tourist type usually invited a family to do travelling to Bogor city with a number of groups of three to five people. They spent more than six hours, but did not stay overnight in Bogor city. Fee and decision to travel to Bogor city were pretty well planned. Money spent approximately was Rp 250.000 - Rp 500.000 and they bought some souvenirs for both family and friends in their hometown. Based on the tourist group profile, the authors named this segment adult family segment.

The use of the term adult family was certainly based on the approach to the character types along with tourists who travelled to Bogor city. In addition, the number of tourist group indicated that this type conducted the tour with her little family so they did not have to stay in Bogor city.

Based on the tourist profile of this second group, the second segment of Bogor city tourists resulting from this study was adult family segments, namely: a. adult visitors who have already worked (private employees) and married;

b. do tourism with a small family with a number of people three to five people;

c. expenses and tourism plans are usually planned;

d. there are the purchase souvenirs.

Around 63 percent of this group chose a culinary tour as the destination of their visit to the Bogor city. However culinary chosen by this group tend to be characterized by originality or only culinary that they could find in Bogor, such as taro product or Bogor pickled that famous. In addition, the location distance or tourism time required is also an important consideration for this group considering they do tourism with family and so we need a strategy for ensuring that a lot of people at one time.

\section{Segmen III (Young Adult Segment)}

This segment is the smallest segment in the number of the Bogor city tourists. Around 6 percent of the Bogor city tourist filled by groups with tourismers from student groups who certainly has not been married. This tourist groups tend to tourism in groups with their friends. Costs incurred by the tourism group was larger than the previous two groups, roughly $\mathrm{Rp} 500.000$ - Rp 1.000 .000 , because this group is almost entirely made visits to tourist stays longer than one night, so that groups of tourists also can make a visit more than 6 times a 
month. However, the decision to tour usually done suddenly or unplanned. Based on third-profile tourist groups, the authors named this segment as a young adult segment.

Based on the tourist profile of this third group, the third segment of the Bogor city tourists resulting from this research is the young adult segment, namely:

a. adult visitors who are not yet working / student (the income of the parents);

b. travel with a group of friends;

c. spend quite large and do more than one night tourism;

d. high visit intensity.

Segments filled by the student group had something in common with the previous group in the form of a tourist destination - a culinary tour. Moreover, despite spending more than one night to tourism, this group tended to choose the accommodation, which was efficent. Therefore, the ease of finding the location was very important. This related to the presence or absence of public transport to the venue. Popularity also was an important consideration for this tourist group to travel, for this young group currently has the habit of always up to date.

\section{Analysis of Tourist Preferences to Bogor Typical Culinary Tour}

Consumer preferences indicated that consumer favorite products are from a wide selection of existing products. Level of fondness was seen from one attribute with each other. Thus, it would directly be the comparison of more than one attribute of a product that will be chosen by consumers in accordance with the most favorite product. By knowing the consumer preferences of the attributes of a product, it will be very helpful in the process of developing a business based on the consumer preferences.

In this research, analysis of the preferences of Bogor city tourist to culinary attributes by using conjoint analysis which used a Likert scale as a judge. There were three attributes used from Bogor typical culinary tour, namely other culinary products, the location of the tourism, and the services provided on the culinary tour. For culinary tourism product attributes were divided into several sub-factors or so-called level, such as tourist facilities, the popularity of the tourist area, tour originality, and the cost to tourism. While the extent to attribute a tourist location is the distance / tourism time and the ease of tourism search, as well as the level of service attributes to comfortability in a tourist location and friendly service.

The results of the conjoint analysis were a form of utility or utility value of each attribute asked to tourists. The amount of the utility value will show that these attributes are preferred over other attributes. In addition, conjoint analysis can also inform the importance of each attribute (\% utility range). Great value will also showed its importance in the view of tourists. The purpose of this study was to determine the attributes preferred and considered important by tourists who will formulate into a proper strategy for the development of Bogor typical culinary as can be seen in Table 5 . 
Table 5. Utility Value and Interest Value of Product, Location and Services of Bogor Typical Culinary

\begin{tabular}{llcc}
\hline Attribute & \multicolumn{1}{c}{ Level } & Utility Value & $\begin{array}{c}\text { Interest Value } \\
(\% \text { utility range })\end{array}$ \\
\hline \multirow{4}{*}{ Product } & Tour Facilities & 0,156 & 67,14 \\
& Popularity of tour areas & $-0,149$ & \\
& Tour originality & $-0,026$ & \\
& Cost for tour & 0,019 & 1,43 \\
\multirow{2}{*}{ Location } & Location distance/time of & $-0,003$ & \\
& tour & 0,003 & 31,43 \\
& East of tour location search & $-0,071$ & \\
\hline
\end{tabular}

From Table 5, it can be seen that tourists prefer to choose product attribute as a major important factor to determine the choice of Bogor typical culinary tourism with a percentage of 67.14 percent, while the service was the second in the level of interest wit a percentage of 31.43 percent, but it could be concluded that for Bogor city tourist, Bogor typical culinary tourist location is in fact not an important factor in making a decision as to their importance was 1.43 percent. The opinions of the respondents will be represent the voice of Bogor city tourist in choosing Bogor typical culinary tour for Pearson's correlation values sampled enough of its $R$, that is 0.765 , while significant values of less than 0.05 , namely 0.014 showed an accuracy to predict and indicate regression models that has been already formed well, or in other words, multiple linear regression model is suitable or appropriate for data analyzed.

Based on further analysis of the utility value of each level of the attribute, it can be seen that the level of product attributes tourist facilities have the greatest utility value (0.156) compared to the level of other product attributes. While on the attributes of the location, the ease to find tourism location was greater than the distance/ tourism time, that is, 0.003 . Furthermore, the utility value and friendly service level were greater than the level of comfortability at tourist location on Bogor typical culinary tourism service attributes, which amounted to 0.071. Based on this analysis, it can be concluded that, tourist preferences of Bogor city to the Bogor typical culinary has characteristics of typical form of culinary areas of Bogor which has a complete tourist facilities, the ease of finding the location and the friendly service of the culinary attractions. The results of this study resembled previous research with the object in the form of regional specialties and subjects, such as tourists with preference in the form of products, services and location of the sale of food typical of the region (Amuquandoh, 2013).

\section{Managerial implications}

Based on these results, the consumer to the object of study required a complete product offer. This can be met by the seller presenting the complete product in one location. Both of them were done by the seller or more than one sellers working together in one location to present a selection of Bogor typical products culinary that diverse and complete. 
The results of this study indicated that, prices or costs incurred by tourists had the second-highest level of importance on product attributes. This study showed high and low prices which do not influence the purchasing decisions if the price was in accordance with the products on offer and if consumers can have a variety of desirable products in one place, the consumers' willingness to pay would increase.

Form of active promotion was seen very appropriately for the development of Bogor typical culinary considering that every consumer has a preference level that is different from others (Ulfah 2015). Due to the current trends, one of the breakthrough forms is the online sale through social media, such as Facebook, Twitter, Instagram which made it more accessible to the general public. Government or business doers can explain the product, tourist location, the facilities offered interestingly so that tourists would get hospitality of the service.

\section{Conclusion}

\section{Conclusion and Recommendation}

Segmentation and profiling Bogor City tourism with a cluster analysis resulted in three groups of or segment tourists with profiles as follows: (a) the first segment (single adult segment); (B) the second segment (married adult segment); and (c) the third segment (young adult segment).

Bogor City tourist preferences choose Bogor typical culinary tour with characteristics typical form of Bogor culinary location which has complete tourist facilities, the ease of finding the location, and the friendly service of that culinary tour location. The factors that influence this preference is the product, location and service of Bogor typical culinary.

The strategy was formulated to develop Bogor typical culinary tourism, namely to make a breakthrough in terms of marketing, the making or promotion of standardization policy by the government to businesses doers of Bogor typical culinary and establish centralization of Bogor typical culinary tourism.

\section{Recommendation}

This research was conducted at Bogor typical culinary tourism in general, so more research is needed to deepen its analysis of consumer preferences and segmentation of the Bogor typical culinary tourism. This can be done through more specific research on some Bogor typical culinary tourism products and, more in-depth details of the respondents as the consumer of Bogor typical culinary tour.

\section{Reference}

Adiyoga, W., Nurmalinda. (2012). Conjoint analysis of consumer preferences towards product attributes potato, onion and red pepper. J. Hort., 22, 292302.

Burhanuddin, Masithoh, S., Atmakusuma, J. 2002. Analysis of preferences and consumption patterns buffalo meat to householders in Pandeglang. Med. Pet, 25, 1-6. 
Amuquandoh, F. E., Ramos, A. (2013). Traditional food preferences of tourists in Ghana. British Food Journal, 115, 987 - 1002.

Guler, O et al. (2016). What is Your Favorite Local Food Menu ? Application of Conjoint Analysis on The Eastern Mediterranean Cuisine of Turkey. Journal of Tourism and Gastronomy Studies, 4/3, 38 - 52.

Hanis, A. 2013. Consumer's preferences for eggs attributes in Malaysia : evidence from conjoint survey. International Food Research Journal, 5, 2865 - 2872.

Kembaren, S. C., Build, P., Sitepu, R. (2014). Tourism preference to visit Samosir Island tour with conjoint analysis. Saintia Mathematics, 3, 267-275.

Kivela, J. J. (1997). Restaurant Marketing: Selection and Segmentation in Hongkong. International Journal of Contemporary Hospitality, 9, 116-123.

Maraseta, G., Wilandari, Y., Sudarno. 2014. Pairwise-comparison conjoint analysis to determine the level of interest of the attributes of a tourism bureau. Journal of the Gaussian, 3, 391-400

Mulyadi, Andri, Fauziyah, E. 2014. Consumer preferences in the purchase of instant noodles in Bangkalan. Agriekonomik, 3, 65-80.

Murphy, M., Cowan, C., Henchion, M., O' Reilly, S. 2000. Irish consumer's preferences for honey: a conjoint approach. British Food Journal, 8, 585 598.

Palupi, N.S., Muhandri, T., Subarna. (2014). Consumer preferences and traders meatball noodles against corn wet noodles extrusion technologies. MPI Journal, 2, 204-212.

Suherlan, H., Hidayah, N. (2015). Attitude towards tourists culinary tourism product in Palembang. Journal of Tourism Ilmiaah STP Trisakti, 20, 1-13.

Sumarwan, U. (2011). Consumer Behavior: Theory and Practice in Marketing. Bogor: Ghalia Indonesia.

Swantari, A. (2013). Culinary tourism potential in Kemang Pratama, Bekasi. Mittra, 3 (2), 1-22.

Syahrir, Taridala, Bahari. (2015). Consumer preferences labeled rice. Agriekonomika, 4, 10-21.

Tripathi, S.N., Masood, H.S. 2010. An empirical study of tourist preferences using conjoint analysis. Int. Journal of Business Science and Applied Management, 2, 01-16.

Vanhonacker, F., Lengard, V., Hersleth, M., Verbeke, W. (2010). Profiling European traditional food consumers. British Food Journal, 112, $871-886$. 